\title{
Efektivitas Ekstrak Daun Nerium oleander L. terhadap Populasi dan Intensitas Serangan Spodoptera exigua (Hubner.) dan Pengaruhnya pada Produksi Bawang Merah
}

The effectiveness of Nerium oleander L. leaf extract on the population, intensity of attacks by Spodoptera exigua (Hubner.) and its effect on shallot production

\author{
Author(s): Burhanuddin Haji Nasir ${ }^{(1) *}$; Moh. Hibban Toana ${ }^{(1)}$ Idham $^{(1)}$; \\ Sri Anjar Lasmini ${ }^{(1)}$ \\ (1) Universitas Tadulako \\ * Corresponding author: burhanuddin.hnasir@gmail.com
}

\begin{abstract}
ABSTRAK
Penggunaan insektisida dalam pengendalian hama telah menimbulkan berbagai dampak negatif terutama terjadinya kerusakan ekosistem pertanaman. Upaya yang dapat dilakukan untuk mengurangi penggunaan insektisida kimia sintetis adalah dengan memanfaatkan bahan tanaman yang berpotensi sebagai pestisida nabati. Tumbuhan bunga mentega (Nerium oleander Linn.) memiliki potensi sebagai insektisida nabati karena mengandung zat oleandrin yang dapat bekerja sebagai racun perut dan penghambat daya makan larva. Penelitian ini bertujuan untuk mengetahui pengaruh berbagai konsentrasi ekstrak daun bunga mentega N. Spodoptera oleander pada pertanaman bawang merah verietas Lembah Palu Allium cepa var. aggregatum exigua Hubner. terhadap padat populasi dan intensitas serangan hama ulat bawang Spodoptera exigua dan hasil produksi bawang merah di lahan kering. Penelitian dilaksanakan pada bulan Mei 2018 sampai bulan Februari 2019. di Desa Sidera, Kecamatan Sigi Biromaru Kabupaten Sigi, Provinsi Sulawesi Tengah. Penelitian menggunakan Rancangan Acak Kelompok (RAK) dengan 6 perlakuan yaitu K0: tanpa ekstrak, K1: ekstrak N. oleander 2,69 g/L, K2: ekstrak $N$. oleander 5,38 g/L, K3: ekstrak N. oleander 10,75 g/L, K4: ekstrak $N$. oleander 21,5 g/L, dan K5: ekstrak $N$. oleander 43,0 g/L. Variabel pengamatan meliputi padat populasi dan intensitas serangan ulat bawang $S$. exigua dan produksi bawang merah. Data yang diperoleh dianalisis dengan menggunakan analisis varians yang dilanjutkan dengan uji BNJ 5\%. Hasil penelitian menunjukkan bahwa konsentrasi 43,0 g/L menekan populasi dan intensitas serangan larva $\mathrm{S}$. exigua masing-masing sebesar 1,58 ekor menjadi 0,71 ekor dan $2,79 \%$ menjadi $0,71 \%$. Produksi yang dicapai meningkat pada perlakuan K5 yakni dari 4,97 t/ha menjadi 8,67 t/ha.
\end{abstract}

Keywords:

Nerium oleander $L$. extract;

Spodoptera exigua Hubner.

\section{ABSTRACT}

Excessive use of insecticides in pest control causes various negative impacts, especially damage to agricultural ecosystems. To reduce chemical insecticides by utilizing plants that have potential as vegetable pesticides. Nerium oleander Linn. has the potential as a botanical insecticide because it contains oleandrin, which functions as a gastric poison and inhibits feeding of larvae. This study aimed to determine the effect of $N$. oleander leaf extract on population density and attack intensity of Spodoptera exigua and shallot yields on dryland. The study was conducted from May 2018 to February 2019. in Sidera Village, Sigi Biromaru District, Sigi Regency, Central Sulawesi. The study used a randomized block design with 6 treatments, namely K0: without extract, K1: N. oleander extract 2.69 $\mathrm{g} / \mathrm{L}, \mathrm{K} 2: \mathrm{N}$. oleander extract $5.38 \mathrm{~g} / \mathrm{L}, \mathrm{K} 3: \mathrm{N}$. oleander extract $10,75 \mathrm{~g} / \mathrm{L}, \mathrm{K} 4: \mathrm{N}$. oleander extract $21.5 \mathrm{~g} / \mathrm{L}$, and $\mathrm{K} 5: \mathrm{N}$. oleander extract $43.0 \mathrm{~g} / \mathrm{L}$. The variables observed included population density and S. exigua attack intensity and shallot production. Data were analyzed using analysis of variance followed by the 5\% BNJ test. The results showed that $N$. oliander leaf extract with a concentration of $43.0 \mathrm{~g} / \mathrm{L}$ was able to suppress the population and intensity of S. exigua larvae attack from 1.58 to 0.71 and $2.79 \%$ to $0.71 \%$, respectively. The yield of shallots increased from $4.97 \mathrm{t} / \mathrm{ha}$ to $8.67 \mathrm{t} / \mathrm{ha}$. 


\section{PENDAHULUAN}

Bawang merah varietas Lembah Palu (Allium cepa L. var. aggregatum) merupakan salah satu komoditas hortikultura yang tidak dapat ditinggalkan oleh masyarakat Lembah Palu dan sekitarnya. Bawang merah tersebut merupakan bawang merah lokal yang dibudidayakan secara tradisional oleh petani Lembah Palu. Dalam kehidupan sehari-hari Selain berguna sebagai penyedap masakan dan membuat penambah selera makanan dengan aromanya yang khas. Bawang merah mengandung senyawa fungsional termasuk organosulfur, antosianin, flavonoid, quercetin, kaempferol dan polifenol (Arshad et al., 2017).

Bawang merah varietas Lembah Palu merupakan salah satu komoditas unggulan Sulawesi Tengah dan merupakan bahan baku industri pengolahan bawang goreng serta telah menjadi "Brand Lokal" kota Palu. Salah satu keunikan bawang merah tersebut yang membedakan dengan bawang merah lainnya adalah umbinya yang mempunyai tekstur yang padat sehingga menghasilkan bawang goreng yang renyah dan gurih serta aroma yang tidak berubah walaupun disimpan lama dalam wadah yang tertutup (Dinas Pertanian Sulawesi Tengah, 2012).

Badan Pusat Statistik Provinsi Sulawesi Tengah menunjukkan pada tahun 2017 luas lahan panen bawang merah mencapai 1.297 ha, dengan produksi mencapai 11.511 ton, dengan hasil per hektar mencapai 8,75 t/ha, mengalami penurunan produksi menjadi 4,12 t/ha pada tahun 2018. (BPS Provinsi Sulawesi Tengah, 2019). Berbagai upaya untuk meningkatkan produktifitas bawang merah diantaranya adalah perbaikan teknik budidaya, namun permasalahan hama dan penyakit menjadi salah satu faktor yang menentukan dalam peningkatan produktivitas bawang merah.
Hama utama yang menyerang tanaman bawang merah adalah Spodoptera exigua (Wang et al., 2018). Kehilangan hasil yang disebabkan oleh hama tersebut dapat mencapai 20-70\% (Aldini et al., 2020). Menurut Ueno (2015) ulat bawang S. exigua merupakan salah satu hama tanaman bawang merah yang menyerang sepanjang tahun, baik pada musim kemarau maupun pada musim hujan.

Pada umumnya para petani bawang merah khususnya di Lembah Palu masih mengandalkan penyemprotan pestisida sintetik yang dilakukan 2-3 hari sekali untuk mengatasi serangan ulat S.exigua dengan menggunakan dosis tinggi bahkan dengan mencampur beberapa jenis pestisida dalam satu kali aplikasi (Ahmad et al., 2008). Pengendalian dengan cara tersebut dianggap lebih efektif karena dapat menurunkan populasi hama dalam waktu yang relatif singkat, tetapi penggunaaan pestisida secara terus menerus dan berlebihan dapat menimbulkan dampak negatif seperti terjadinya resistensi hama, resurjensi, masalah residu, pencemaran lingkungan dan terbunuhnya musuh alami hama serta berdampak buruk terhadap organisme yang bukan sasaran seperti manusia (Damalas \& Eleftherohorinos, 2011; Kim et al., 2017) dan kerusakan ekosistem (Aktar et al., 2009; Meena et al., 2020; Wang et al., 2018)

Untuk mengurangi dampak negatif dari penggunaan pestisida sintetis dapat dilakukan dengan penggunaan bahanbahan alam sebagai bahan pengendali hama ramah lingkungan. Berbagai jenis tumbuhan yang bersifat insektisidal telah dilaporkan oleh banyak peneliti seperti ekstrak tumbuhan andaliman (Zanthoxylum acanthopodium) dan jambu mete (Anacardium occidentale) sebagai insektisida nabati untuk ulat kubis Plutella xylostella dan apis Brevicoryne brassicae (Osabutey et al., 2018), ekstrak nimba 
(Azadirachta indica) untuk pengendalian Sitophilus zeamais pada biji jagung (Islam, 2017), S. littoralis (Boisd.) pada tanaman kapas dan S. exigua (Hubner) pada tanaman bawang merah (Sukirno, 2017), ekstrak daun sirsak (Annona muricata) untuk pengendalian Riptortus linearis pada tanaman kedelai (Rahmawati et al., 2019), ekstrak daun pepaya (Carica papaya L.) untuk pengendalian Leptocorisa acuta pada tanaman padi (Listianti et al., 2019), serta ekstrak bunga mentega (Nerium oleander) sebagai pengawet berbagai jenis kayu-kayuan (Goktas et al., 2007), sebagai larvasida (El-Akhal et al., 2015; Salim et al., 2020), herbisida (Al-Samarai et al., 2018) dan insektisida (Salim et al., 2016).

Bagian tanaman $N$. oleander yang dapat digunakan sebagai insektisida nabati adalah akar, batang, kulit batang, daun dan bunga, tetapi yang paling sering digunakan adalah daunnya karena paling banyak mengandung oleandrin. Zat tersebut bekerja sebagai racun perut dan penghambat daya makan larva. Racun perut akan mempengaruhi metabolisme larva setelah memakan racun, kemudian racun akan masuk ke dalam tubuh dan dicerna dalam saluran tengah yang setelah diedarkan bersama cairan yang fungsinya seperti darah. Racun yang terbawa cairan tersebut akan mempengaruhi sistem saraf larva dan kemudian akan menimbulkan kematian (Roni et al., 2013). Penggunaan $N$. oleander untuk pengendalian hama ulat bawang belum perna dilakukan sehingga menjadi penting untuk dilakukan pengujian agar dapat dioptimalkan penggunaannya.

Penelitian bertujuan untuk mengetahui efektivitas ekstrak daun tumbuhan bunga mentega $N$. oleander sebagai insektisida nabati terhadap populasi dan intensitas serangan hama ulat bawang di lahan kering.

\section{METODOLOGI}

Penelitian dilaksanakan di Desa Sidera, Kecamatan Sigi Biromaru Kabupaten Sigi, Provinsi Sulawesi Tengah dan berlangsung pada bulan Mei 2018 sampai dengan bulan Februari 2019. Alat yang digunakan yaitu blender, cangkul, handsprayer, timbangan analitik, gelas ukur, ember, cutter, ayakan, tangki semprot, hand sprayer, kain kasa, kamera, erlenmeyer. Bahan yang digunakan adalah benih bawang merah varietas Lembah Palu, ekstrak daun $N$. oleander, pupuk kandang sapi, pupuk NPK, dan aquades.

Penelitian menggunakan Rancangan Acak Kelompok (RAK), dengan 6 perlakuan dan diulang sebanyak 4 kali sehingga diperoleh 24 unit perlakuan. Perlakuan tersebut adalah K0 : tanpa ekstrak, K1: ekstrak daun $N$. oleander konsentrasi 2,69 g/L, K2 : ekstrak daun $N$. oleander konsentrasi 5,38 g/L, K3: ekstrak daun $N$. oleander konsentrasi 10,75 g/L, K4: ekstrak daun $N$. oleander konsentrasi $21,5 \mathrm{~g} / \mathrm{L}$, dan $\mathrm{K} 5$ : ekstrak daun $N$. oleander konsentrasi 43 g/L.

Pelaksanaan penelitian diawali dengan pengolahan tanah yang dilakukan sebanyak dua kali. Tahap pertama untuk memecah tanah dan membersihkan sisasisa tanaman dan gulma dengan menggunakan handtraktor dan tahap kedua untuk menggemburkan tanah dengan menggunakan cangkul. Selanjutnya diratakan dan dibuat bedengan dengan ukuran $2 \times 1 \mathrm{~m}^{2}$, dan jarak antara bedeng adalah $50 \mathrm{~cm}$.

Penanaman dilakukan satu minggu setelah pemberian pupuk kandang. Sebelum dilakukan penanaman terlebih dahulu benih bawang merah diseleksi dengan cara memilah benih yang baik dan tidak baik, selanjutnya dikelompokkan menjadi 3 kelompok yaitu benih yang berukuran kecil, sedang, dan besar. Selanjutnya bagian ujung dipotong untuk menyeragamkan pertumbuhan tunas, lalu benih yang telah diseleksi langsung 
ditanam pada petak percobaan. Benih ditanam tegak lurus dengan jarak tanam $15 \mathrm{~cm} \times 15 \mathrm{~cm}$. Untuk setiap bedeng ditanam sebanyak 78 benih. Sehari sebelum penanaman bedengan percobaan disiram sampai kapasitas lapang. Penanaman bawang merah dilakukan dengan cara manual.

Pemupukan dilakukan sebanyak 2 kali yaitu pupuk kandang sebagai pupuk dasar, dengan dosis $2,5 \mathrm{~kg} /$ petak diberikan cara disebar merata satu minggu sebelum tanam pada luas petak $2 \times 1 \mathrm{~m}$. Pemupukan susulan dilakukan dua minggu setelah tanam dengan menggunakan pupuk NPK dosis $100 \mathrm{~g} /$ petak.

Penyiraman dilakukan sehari dua kali setiap pagi dan sore sampai tanaman berumur 14 hari. Selanjutnya frekuensi penyiraman dilakukan satu hari sekali sampai umur tanaman 55 hari. Pemeliharaan tanaman meliputi pengendalian gulma yang dilakukan secara fisik dengan mencabut gulma kemudian dibenamkan kembali. Pengendalian dilakukan menyesuaikan dengan kondisi lapangan.

Pengaplikasian ekstrak daun $N$. oleander dilakukan secara berjadwal setiap 1 minggu sekali dimulai pada 1 minggu setelah tanam (MST) sampai dengan 6 MST menggunakan hand sprayer kapasitas $1000 \mathrm{~mL}$. Aplikasi dilakukan secara merata keseluruh bagian tanaman.

Parameter yang diamati meliputi

kepadatan populasi larva dan intensitas serangan larva S.exigua serta produksi bawang merah. Pengamatan Populasi larva dihitung secara langsung pada 20 tanaman sampel per petak yang telah ditandai menggunakan label, dilakukan pada 2 MST sampai dengan 7 MST. Intensitas serangan diamati pada setiap 20 tanaman sampel per petak yang telah ditandai menggunakan sepotong tangkai kayu yang pucuknya diberi cat merah dilakukan pada 2 MST sampai dengan 7 MST. Intensitas serangan dihitung dengan menggunakan rumus mutlak yaitu:

$$
\mathrm{I}=\frac{\mathrm{a}}{\mathrm{b}} \times 100 \%
$$

\section{Keterangan :}

I: intensitas serangan (\%)

a: jumLah tanaman yang terserang

b: jumLah total sampel tanaman yang diamati.

Pengamatan produksi dilakukan, dengan menimbang berat umbi bawang merah pada saat panen dari setiap plot perlakuan (g/petak), kemudian dikonversi kedalam $\mathrm{t} / \mathrm{ha}$. dengan menggunakan rumus

$$
\mathrm{Y}\left(\frac{\text { ton }}{\mathrm{ha}}\right)=\frac{\mathrm{X}(\mathrm{kg})}{\mathrm{L}\left(\mathrm{m}^{2}\right)} \mathrm{X} \frac{10.000 \mathrm{~m}^{2}}{1000 \mathrm{~kg}} \mathrm{X} 80 \%
$$

Keterangan:

$\mathrm{Y}=$ Produksi dalam $\mathrm{t} / \mathrm{ha}$

$\mathrm{X}=$ Produksi dalam $\mathrm{kg} /$ petak

$\mathrm{L}=$ Luas Petak

Data yang diperoleh dilakukan analisis ragam (Anova) menggunakan software PAST (PAleontological Statistics). Jika analisis ragam menunjukkan adanya pengaruh, maka dilanjutkan dengan Uji Beda Nyata Jujur (BNJ) dengan tingkat ketelitian 95\%.

\section{HASIL DAN PEMBAHASAN}

Kepadatan populasi $S$. exigua

Hasil pengamatan populasi $S$. exigua pada tanaman bawang merah Lembah Palu disajikan pada Tabel 1. Analisis ragam menunjukkan bahwa perlakuan yang diberikan berpengaruh nyata terhadap populasi $S$. exigua. 
Tabel 1. Rata-rata Kepadatan Populasi Larva S. exigua pada Pertanaman Bawang Merah Lembah Palu (ekor).

Table 1. Population density of S. exigua in the Lembah Palu shallot field

\begin{tabular}{|c|c|c|c|c|c|c|}
\hline \multirow{2}{*}{$\begin{array}{l}\text { Perlakuan } \\
\text { Treatment }\end{array}$} & \multicolumn{6}{|c|}{ Padat populasi } \\
\hline & $2 \mathrm{MST}$ & $3 \mathrm{MST}$ & $4 \mathrm{MST}$ & $5 \mathrm{MST}$ & $6 \mathrm{MST}$ & $7 \mathrm{MST}$ \\
\hline \multirow[t]{2}{*}{ Tanpa ekstrak } & 2,25 & 2,75 & 3,50 & 3,00 & 2,25 & 2,00 \\
\hline & $(1,65)^{\mathrm{e}}$ & $(1,79)^{\mathrm{d}}$ & $(1,98)^{\mathrm{d}}$ & $(1,86)^{\mathrm{d}}$ & $(1,65)^{d}$ & $(1,58)^{\mathrm{e}}$ \\
\hline \multirow[t]{2}{*}{ Ekstrak 2,69 g/L } & 1,75 & 2,00 & 2,75 & 2,50 & 1,75 & 1,75 \\
\hline & $(1,49 b)^{\mathrm{de}}$ & $(1,58)^{\mathrm{c}}$ & $(1,80)^{\mathrm{cd}}$ & $(1,73)^{\mathrm{d}}$ & $(1,49)^{\mathrm{c}}$ & $(1,49)^{\mathrm{cd}}$ \\
\hline \multirow[t]{2}{*}{ Ekstrak 5,38 g/L } & 1,50 & 1,50 & 2,00 & 1,75 & 1,00 & 1,50 \\
\hline & $(1,40)^{\mathrm{cd}}$ & $(1,40)^{\mathrm{c}}$ & $(1,56)^{\mathrm{c}}$ & $(1,49)^{\mathrm{c}}$ & $(1,22)^{b}$ & $(1,40)^{\mathrm{c}}$ \\
\hline \multirow[t]{2}{*}{ Ekstrak 10,75 g/L } & 1,00 & 1,50 & 2,00 & 1,50 & 1,00 & 0,75 \\
\hline & $(1,22)^{\mathrm{c}}$ & $(1,39)^{\mathrm{c}}$ & $(1,56)^{\mathrm{c}}$ & $(1,40)^{\mathrm{c}}$ & $(1,22)^{\mathrm{b}}$ & $(1,10)^{\mathrm{b}}$ \\
\hline \multirow{2}{*}{ Ekstrak 21,5 g/L } & 0,50 & 0,50 & 0,75 & 1,00 & 0,25 & 0,00 \\
\hline & $(0,97)^{\mathrm{b}}$ & $(0,97)^{\mathrm{b}}$ & $(1,10)^{b}$ & $(1,18)^{\mathrm{b}}$ & $(0,84)^{\mathrm{a}}$ & $(0,71)^{\mathrm{a}}$ \\
\hline \multirow[t]{2}{*}{ Ekstrak $43 \mathrm{~g} / \mathrm{L}$} & 0,00 & 0,00 & 0,00 & 0,00 & 0,25 & 0,00 \\
\hline & $(0,71)^{\mathrm{a}}$ & $(0,71)^{\mathrm{a}}$ & $(0,71)^{\mathrm{a}}$ & $(0,71)^{\mathrm{a}}$ & $(0,84)^{\mathrm{a}}$ & $(0,71)^{\mathrm{a}}$ \\
\hline BNJ 5\% & $\mathbf{0 , 1 8}$ & $\mathbf{0 , 2 0}$ & $\mathbf{0 , 2 7}$ & $\mathbf{0 , 1 9}$ & $\mathbf{0 , 1 6}$ & 0,18 \\
\hline
\end{tabular}

Rata-rata kepadatan populasi larva S. exigua tertinggi terdapat pada pengamatan ketiga atau 4 MST yaitu terdapat pada perlakuan tanpa ekstrak (kontrol), sedangkan terendah terdapat pada perlakuan ekstrak $43 \mathrm{~g} / \mathrm{L}$. Dari hasil penelitian yang dilakukan menunjukkan bahwa ekstrak $N$. oleander dapat menekan laju kepadatan populasi $S$. exigua yang ditandai oleh rendahnya populasi pada setiap minggu atau setiap pengamatan yang dilakukan dibandingkan dengan kontrol.

Pengaruh ekstrak $N$. oleander terhadap populasi larva $S$. exigua disebabkan adanya kandungan bioaktif yang terdapat pada tumbuhan secara alami. Seperti yang dikemukakan bahwa pestisida nabati merupakan produk alam yang berasal dari tumbuhan yang mengandung bioaktif seperti alkaloid senyawa sekunder yang jika diaplikasikan ke hama sasaran, dapat mempengaruhi sistem syaraf, terganggunya sistem reproduksi, keseimbangan hormon, perilaku berupa penarik atau pemikat, penolak, mengurangi nafsu makan dan terganggunya sistem pernafasan.

Ekstrak daun bunga mentega $N$. oleander memberikan pengaruh sangat nyata terhadap berkurangnya kepadatan populasi larva $S$. exigua pada tanaman bawang merah. Hal ini disebabkan karena kandungan senyawa aktif daun bunga mentega $N$. oleander yang terdiri glycosida berupa senyawa oleandrin yang memiliki sifat insektisida dan antifeedant. Menurut Salim et al.(2016) ekstrak $N$. oleander yang bersifat penghambat nafsu makan (antifeedant) menyebabkan larva menjadi berkurang nafsu makannya sehingga panjang tubuhnya menjadi pendek. Penelitian tersebut sesuai dengan yang dilaporkan oleh Taufika et al. (2020) yang mengemukakan bahwa ekstrak daun srikaya (Annona squamosa L.) dan rimpang kunyit (Curcuma domestica Val.) berfungsi sebagai insektisida nabati karena dapat 
memperpanjang stadium larva dan pupa, mengurangi berat pupa, sayap imago tidak berkembang sempurna, pengurangan ukuran imago, serta imago tidak mampu menghasilkan telur pada larva S. litura.

Dengan semakin meningkatnya konsentrasi yang diberikan maka akan menyebabkan semakin pendeknya lebar tubuh, pendeknya panjang tubuh, dan semakin berkurangnya berat larva. Racun yang terkandung dalam daun menyebabkan larva menjadi berkurannya nafsu makan sehingga lebar dan berat larva menjadi berkurang. Untuk meningkatkan efektivitas pestisida nabati dapat ditambahkan dekomposer berupa EM4 atau air cucian beras (Juli \& Wahyuni, 2020).

Berdasarkan hasil penelitian yang dilakukan menunjukkan bahwa semakin meningkat konsentrasi yang diberikan maka racun perut yang masuk kedalam tubuh larva akan semakin banyak sehingga larva akan semakin banyak mengalami kematian. Hal tersebut karena ekstrak daun $N$. oleander dapat berperan sebagai insektisida nabati yang bertipe racun perut dan penghambat daya makan larva (Ogunnupebi et al., 2020; Salim et al., 2016). Hasil penelitian tersebut sesuai yang dilaporkan Kamelia et al. (2020) bahwa kombinasi ekstrak $20 \mathrm{~mL}$
Cymbopogon nardus dan $80 \mathrm{~mL}$ Nicotiana tabacum menyebabkan mortalitas Helopeltis antonii sebesar 93,30\%, dan nilai $\mathrm{LC}_{50}$ ekstrak Tithonia diversifolia pada larva Plutella xylostella diperoleh pada konsentrasi 0,067\% (Firmansyah et al., 2018).

Racun perut akan mempengarui metabolisme larva setelah memakan racun, kemudian racun akan masuk kedalam tubuh, dicerna dalam saluran tengah yang kemudian diedarkan bersama darah. Racun yang terbawa darah akan mempengaruhi sistem saraf larva dan kemudian akan menimbulkan kematian (Cruz-Estrada et al., 2013; Roni et al., 2013).

\section{Intensitas serangan $S$. exigua}

Rata-rata intensitas serangan $S$. exigua pada tanaman bawang merah Lembah Palu disajikan pada Tabel 2. Analisis ragam menunjukkan bahwa perlakuan yang diberikan berpengaruh nyata. Intensitas serangan pada perlakuan tanpa ekstrak lebih tinggi dibandingkan dengan semua perlakuan lainnya sedangkan perlakuan ekstrak 21,5 $\mathrm{g} / \mathrm{L}$ dan $43 \mathrm{~g} / \mathrm{L}$ memiliki intensitas serangan yang paling rendah dan berbeda nyata dengan perlakuan lainnya.

Tabel 2. Rata-rata Intensitas Serangan Larva S. exigua pada Pertanaman Bawang Merah Lembah Palu (\%).

Table 2. Intensity attack of A. exigua in the Lembah Palu shallot field (\%)

\begin{tabular}{ccccccc}
\hline \multirow{2}{*}{$\begin{array}{c}\text { Perlakuan } \\
\text { Treatment }\end{array}$} & \multicolumn{5}{c}{ Intensitas serangan } \\
& $2 \mathrm{MST}$ & $3 \mathrm{MST}$ & $4 \mathrm{MST}$ & $5 \mathrm{MST}$ & $6 \mathrm{MST}$ & $7 \mathrm{MST}$ \\
\cline { 2 - 7 } Tanpa ekstrak & 11,27 & 12,75 & 16,25 & 13,75 & 11,25 & 7,50 \\
& $(3,41)^{\mathrm{c}}$ & $(3,76)^{\mathrm{d}}$ & $(4,08)^{\mathrm{c}}$ & $(3,76)^{\mathrm{c}}$ & $(3,41)^{\mathrm{b}}$ & $(2,79)^{\mathrm{b}}$ \\
Ekstrak 2,69 g/L & 8,75 & 11,25 & 13,75 & 10,00 & 8,75 & 6,25 \\
& $(3,02)^{\mathrm{c}}$ & $(3,41)^{\mathrm{c}}$ & $(3,76)^{\mathrm{c}}$ & $(3,24)^{\mathrm{c}}$ & $(3,02)^{\mathrm{b}}$ & $(2,57)^{\mathrm{b}}$ \\
Ekstrak 5,38 g/L & 8,75 & 10,00 & 12,50 & 10,00 & 6,25 & 5,00 \\
& $(2,97)^{\mathrm{c}}$ & $(3,24)^{\mathrm{c}}$ & $(3,59 \mathrm{~b})^{\mathrm{c}}$ & $(3,24)^{\mathrm{c}}$ & $(2,57)^{\mathrm{b}}$ & $(2,35)^{\mathrm{b}}$ \\
Ekstrak 10,75 g/L & 5,00 & 7,50 & 11,25 & 6,25 & 5,00 & 3,75 \\
& $(2,35)^{\mathrm{b}}$ & $(2,79)^{\mathrm{c}}$ & $(3,41)^{\mathrm{c}}$ & $(2,57)^{\mathrm{b}}$ & $(2,35)^{\mathrm{b}}$ & $(1,94)^{\mathrm{b}}$ \\
Ekstrak 21,5 g/L & 2,50 & 5,00 & 6,25 & 5,00 & 5,00 & 2,50
\end{tabular}




\begin{tabular}{rcccccc} 
& $(1,53)^{\mathrm{b}}$ & $(2,35)^{\mathrm{b}}$ & $(2,57)^{\mathrm{b}}$ & $(2,16)^{\mathrm{b}}$ & $(2,35)^{\mathrm{b}}$ & $(1,53)^{\mathrm{b}}$ \\
Ekstrak 43 g/L & 0,00 & 0,00 & 0,00 & 1,25 & 1,25 & 0,00 \\
& $(0,71)^{\mathrm{a}}$ & $(0,71)^{\mathrm{a}}$ & $(0,71)^{\mathrm{a}}$ & $(1,12)^{\mathrm{a}}$ & $(1,12)^{\mathrm{a}}$ & $(0,71)^{\mathrm{a}}$ \\
\hline BNJ 5\% & $\mathbf{0 , 5 2}$ & $\mathbf{0 , 3 0}$ & $\mathbf{0 , 4 1}$ & $\mathbf{0 , 6 5}$ & $\mathbf{0 , 5 0}$ & $\mathbf{0 , 6 2}$ \\
\hline
\end{tabular}

Keterangan: * Angka yang diikuti oleh huruf yang sama pada kolom yang sama tidak berbeda nyata pada uji BNJ taraf $5 \%$

** Angka dalam kurung hasil transformasi $\sqrt{x+0.5}$.

Tabel 2 menunjukkan rata-rata intensitas serangan larva $S$. exigua tertinggi terdapat pada pengamatan ke tiga (4 MST) dan terendah pada perlakuan ekstrak 21,5 g/L dan $43 \mathrm{~g} / \mathrm{L}$ pada semua waktu pengamatan. Menurunnya intensitas serangan pada pertanaman bawang merah yang diaplikasikan dengan $N$. oliander berkaitan erat dengan padat populasi. Bila pada popuplasi tinggi akan menyebabkan intensitas serangan menjadi tinggi dan sebaliknya bila padat populasi rendah akan berdampak pada rendahnya intensitas serangan. Intensitas serangan yang rendah juga karena $N$. oliander bersifat antifeedant, sebagaimana yang dilaporkan oleh Osabutey et al. (2018) bahwa ekstrak tumbuhan andaliman (Zanthoxylum acanthopodium) dan Jambu mete (Anacardium occidentale) yang diaplikasikan pada pertanaman kubis dapat mengurangi populasi dan serangan hama kubis Plutella xylostella dan apis Brevicoryne brassicae karena kedua jenis tumbuhan tersebut mengandung senyawa kimia yang berperan sebagai antifeedent, insektisida, dan ovisidal. Lebih lanjut Utami \& Damanhuri (2020) mengemukakan bahwa ekstrak sereh wangi konsentrasi $15 \%$ dapat mengendalikan hama kutu kebul (Bemicia tabaci) karena tanaman sereh wangi mempunyai mekanisme pengendalian berupa antiserangga, insektisida, antifedan, repelen, anti jamur, dan antibakteri.

\section{Poduksi bawang merah}

Produksi bawang merah Lembah Palu disajikan pada Tabel 3. Analisis ragam menunjukkan bahwa rata-rata produksi bawang merah tertinggi pada perlakuan ekstrak $43 \mathrm{~g} / \mathrm{L}$ dan terendah pada perlakuan tanpa ekstrak.

Tabel 3. Rata-rata Produksi Bawang Merah Varietas Lembah Palu.

Table 3. The production of Lembah Palu

\begin{tabular}{|c|c|}
\hline $\begin{array}{l}\text { Perlakuan } \\
\text { Treatment }\end{array}$ & $\begin{array}{c}\text { Produksi (t/ha) } \\
\text { Production }(\mathrm{t} / \mathrm{ha})\end{array}$ \\
\hline Tanpa ekstrak & $4,97^{\mathrm{a}}$ \\
\hline Ekstrak 2,69 g/L & $5,88^{\mathrm{b}}$ \\
\hline Ekstrak 5,38 g/L & $6,21^{\mathrm{c}}$ \\
\hline Ekstrak 10,75 g/L & $7,49^{d}$ \\
\hline Ekstrak $21,5 \mathrm{~g} / \mathrm{L}$ & $7,90^{\mathrm{d}}$ \\
\hline Ekstrak $43 \mathrm{~g} / \mathrm{L}$ & $8,67^{\mathrm{e}}$ \\
\hline BNJ 5\% & $\mathbf{0 , 3 0}$ \\
\hline $\begin{array}{r}\text { rangan: } * \text { angl } \\
\text { ya } \\
\text { sa } \\
\text { pa }\end{array}$ & $\begin{array}{l}\text { diikuti oleh huruf } \\
\text { a pada kolom yang } \\
\text { x berpengaruh nyata } \\
\text { NJ taraf } 5 \% \text {. }\end{array}$ \\
\hline
\end{tabular}

Hasil rata-rata berat bawang merah varietas Lembah Palu per hektar tertinggi terdapat pada perlakuan ekstrak $43 \mathrm{~g} / \mathrm{L}$ sebesar 8,67 t/ha, kemudian diikuti oleh perlakuan ekstrak 21,5 g/L sebesar 7,90 t/ha, ekstrak 10,75 g/L sebesar 7,49 t/ha, ekstrak 5,38 g/L sebesar 6,21 t/ha, ekstrak 2,69 $\mathrm{g} / \mathrm{L}$ sebesar 5,88 t/ha, dan tanpa ekstrak sebesar 4,97 t/ha. Dari hasil penelitian tersebut menunjukkan bahwa aplikasi ekstrak $N$. oleander sebagai insektisida nabati mampu menekan serangan hama $S$. exigua sehingga produksi dapat dicapai secara optimal.

Penggunaan $N$. oleander sebagai insektisida nabati untuk pengendalian $S$. exigua pada pertanaman bawang merah dapat menjadi salah satu pertimbangan untuk diterapkan sebagai alternatif pengganti insektisida kimia sintetis karena ekstrak daun $N$. oleander dapat menekan 
intensitas serangan $S$. exigua dan potensi sumberdaya tersebut banyak ditemukan sebagai tanaman hias di pekarangan rumah maupun di pinggir jalan. Penggunaan ekstrak $N$. oleander sebagai insektisida nabati juga aman dan tidak menimbulkan pencemaran. Hal tersebut sesuai dengan yang dilaporkan oleh Hikal et al. (2017) bahwa pestisida yang berasal dari tanaman aromatik, lebih ramah lingkungan daripada bahan kimia sintetis karena memiliki toksisitas yang rendah pada mamalia, efek yang rendah pada organisme non-target dan mudah terurai.

\section{KESIMPULAN}

Aplikasi ekstrak daun bunga mentega $N$. oleander sebagai insektisida nabati berpengaruh sangat nyata dan dapat menekan laju populasi dan intensitas serangan $S$. exigua. pada pertanaman bawang merah varietas Lembah Palu. Padat populasi dan intensitas serangan tertinggi $S$. exigua terdapat pada perlakuan tanpa ekstrak sedangkan yang terendah terdapat pada ekstrak daun bunga $N$. oleander konsentrasi 43 g/L. Semakin tinggi konsentrasi yang diberikan maka tingkat serangan dan populasi hama $S$. exigua semakin rendah.

Hasil produksi bawang merah verietas Lembah Palu tertinggi terdapat pada konsentrasi $43 \mathrm{~g} / \mathrm{L}$ sebesar 8,67 t/ha sedangkan yang terendah terdapat pada perlakuan tanpa ekstrak sebesar 4,97 t/ha.

\section{UCAPAN TERIMA KASIH}

Penulis menyampaikan terima kasih kepada LPPM Universitas Tadulako yang telah memberikan bantuan dalam pelaksanaan penelitian ini. Juga kepada sdr. Nurrahmat Prabowo yang telah membantu dalam pengambilan data lapangan

\section{DAFTAR PUSTAKA}

Ahmad, R., Arshad, M., Khalid, A., \& Zahir, Z. A. (2008). Effectiveness of
Organic-Biofertilizer Supplemented with Chemical Fertilizers for Improving Soil Water Retention, Aggregate Stability, Growth and Nutrient Uptake of Maize (Zea mays L.). Journal of Sustainable Agriculture, 31(4), 57-77.

Aktar, W., Sengupta, D., \& Chowdhury, A. (2009). Impact of Pesticides Use in Agriculture: Their benefits and Hazards. Interdisciplinary Toxicology, 2(1), 1-12.

Aldini, G. M., Trisyono, Y. A., 尌 Wijonarko, A., Witjaksono, W., \& De Putter, H. (2020). Farmers' Practices in Using Insecticides to Control Spodoptera exigua Infesting Shallot Allium cepa var. aggregatum in the Shallot Production Centers of Java. Jurnal Perlindungan Tanaman Indonesia, 24(1), 75.

Al-Samarai, G. F., Mahdi, W. M., \& AlHilali, B. M. (2018). Reducing Environmental Pollution by Chemical Herbicides Using Natural Plant Derivatives-Allelopathy Effect. Annals of Agricultural and Environmental Medicine, 25(3), 5.

Arshad, M. S., Sohaib, M., Nadeem, M., 琶 Saeed, F., Imran, A., Javed, A., Amjad, Z., Batool, S. M., \& Yildiz, F. (2017). Status and Trends of Nutraceuticals from Onion and Onion by-Products: A critical review. Cogent Food \& Agriculture, 3(1), 1280254.

Badan Pusat Statistik. (2014). Sulawesi Tengah Dalam Angka 2014. BPS. Sulawesi Tengah

Cruz-Estrada, A., Gamboa-Angulo, M., Bórges-Argáez, R., \& Ruiz- 
Sanchez, E. (2013). Insecticidal Effects of Plant Extracts on Immature Whitefly Bemisia tabaci Genn. (Hemiptera: Aleyroideae). Electronic Journal of Biotechnology, 16(1).

Damalas, C. A., \& Eleftherohorinos, I. G. (2011). Pesticide Exposure, Safety Issues, and Risk Assessment Indicators. International Journal of Environmental Research and Public Health, 8(5), 1402-1419.

Dinas Pertanian Sulawesi Tengah (2012). Standard Operation Procedure (SOP) Budidaya Bawang Merah Varietas Palu. Dinas Pertanian Propinsi Sulawesi Tengah, Palu

El-Akhal, F., Guemmouh, R., Ez Zoubi, EQ Y., \& El Ouali Lalami, A. (2015). Larvicidal Activity of Nerium oleander Against Larvae West Nile Vector Mosquito Culex pipiens (Diptera: Culicidae). Journal of Parasitology Research, 2015, 1-5.

Firmansyah, E., Dadang, F., \& Anwar, R. (2018). Toksisitas Ekstrak Tithonia divesifolia Terhadap Larva Plutella xylostella di Laboratorium. Agriprima, Journal of Applied Agricultural Sciences, 2(1), 55-60.

Goktas, O., Mammadov, R., Duru, M. E., Ozen, E., \& Colak, A. M. (2007). Application of Extracts from the Poisonous Plant, Nerium Oleander L., as a Wood Preservative. African Journal of Biotechnology, 6(17), 2000-2003.

Hikal, W. M., Baeshen, R. S., \& Said-Al Ahl, H. A. H. (2017). Botanical Insecticide as Simple Extractives for Pest Control. Cogent Biology, 3, 1404274.
Islam, T. (2017). Evaluation of Some Plant Extracts Against Maize Weevil, Sitophilus zeamais (Coleoptera: Curculionidae) Under Laboratory Conditions. Pakistan Journal of Agricultural Sciences, 54(04), 737-741.

Juli, J., \& Wahyuni, S. (2020).

尌 Penambahan Dekomposer Sebagai Bahan Stimulator Untuk Meningkatkan Efektivitas Pestisida Nabati. Agrica, 13(1), 1-14.

Kamelia, M., Zein, S., Supriyadi, F., \& Chomsyah, D. N. (2020). Kombinasi Ekstrak Cymbopogon nardus L. dan Nicotiana tabacum Sebagai Insektisida Nabati Helopeltis antonii Sign. Agriprima, Journal of Applied Agricultural Sciences, 4(2), 128-135.

Kim, K.-H., Kabir, E., \& Jahan, S. A. EQ (2017). Exposure to Pesticides and the Associated Human Health Effects. Science of The Total Environment, 575, 525-535.

Listianti, N. N., Winarno, W., \& 钢 Erdiansyah, I. (2019). Pemanfaatan Ektrak Daun Pepaya (Carica papaya L.) Sebagai Insektisida Nabati Pengendali Walang Sangit (Leptocorisa acuta) Pada Tanaman Padi. Agriprima, Journal of Applied Agricultural Sciences, 3(1), 81-85.

Meena, R., Kumar, S., Datta, R., Lal, R., 期 Vijayakumar, V., Brtnicky, M., Sharma, M., Yadav, G., Jhariya, M., Jangir, C., Pathan, S., Dokulilova, T., Pecina, V., \& Marfo, T. (2020). Impact of Agrochemicals on Soil Microbiota and Management: A Review. Land, 9(2), 34. 
Ogunnupebi, T. A., Oluyori, A. P., Dada, A. O., Oladeji, O. S., Inyinbor, A. A., \& Egharevba, G. O. (2020). Promising Natural Products in Crop Protection and Food Preservation: Basis, Advances, and Future Prospects. International Journal of Agronomy, 2020, 1-28.

Osabutey, A. F., Eziah, V., Buxton, T., \& Owusu, E. O. (2018). Evaluating the Insecticidal Potential of Aqueous Plant Extracts from Zanthoxylum zanthoxyloides and Anacardium occidentale Against Insect Pest Complexes of Cabbage in An Open Field Experiment. International Journal of Agricultural Science Research, 73(3), 18-23.

Rahmawati, R., Syarief, M., Jumiatun, \& Djenal. (2019). Potensi Ekstrak Daun Sirsak (Annona muricata) pada Pengendalian Hama Penghisap Polong (Riptortus linearis) Tanaman Kedelai. Agriprima, Journal of Applied Agricultural Sciences, 3(1), 22-29.

Roni, M., Murugan, K., Panneerselvam, C., Subramaniam, J., \& Hwang, J.S. (2013). Evaluation of Leaf Aqueous Extract and Synthesized Silver Nanoparticles Using Nerium oleander Against Anopheles stephensi (Diptera: Culicidae). Parasitol Res, 112, 981-990.

Salim, H. A., Alsaady, M. H. M., \& Shiblawi, L. M. (2020). The First Record to Moth of Ocnogyna loewii Zell. (Arctiidae: Lepidoptera) on Wheat Plants in Iraq and Evaluate Efficacy of Some Aqueous Plant Extracts Against Its Caterpillars. Plant Archives, 20(1), 1366-1370.
Salim, H. A., Mosa, K. O., Khalid, H. A., 期 Salman, H., \& Faihan, H. S. (2016). Biological Activity of Some Aqueous Plant Extracts Against Vanessa cardui Linnaeus (Lepidoptera: $\quad$ Nymphalidae). Journal of Entomology and Zoology Studies, 4(5), 262-264.

Sukirno, S. (2017). The Effectiveness of Spinosad and Neem Extract Against Spodoptera littoralis (Boisd.) and Spodoptera exigua (Hubner): Exploring Possibilities to Enhance the Bio-Pesticide Persistence With Natural UV Protectants Under Field-Sunlight Conditions of Saudi Arabia. Pakistan Journal of Agricultural Sciences, 54(04), 743751.

Taufika, R., Sumarmi, S., \& Nugroho, S. A. (2020). Efek Subletal Campuran Ekstrak Daun Srikaya (Annona squamosa L.) dan Rimpang Kunyit (Curcuma domestica Val.) Terhadap Larva Spodoptera litura F. Agromix, 11(1), 66-78.

Ueno, T. (2015). Beet Armyworm Eloptera exigua (Lepidoptera: Noctuidae): a Major Pest of Welsh Onion in Vietnam. Journal of Agriculture and Environmental Sciences, 4(2).

Utami, K. A. S., \& Damanhuri, F. (2020). Pengaruh Insektisida Campuran Daun Kenikir (Cosmos caudatus) dan Serai Wangi (Cymbopogon nardus) Terhadap Hama Kutu Kebul (Bemisia tabaci Genn.) Pada Budidaya Tanaman Kedelai Edamame. Agriprima, Journal of Applied Agricultural Sciences, 4(1), 26-33. 
Wang, X., Xiang, X., Yu, H., Liu, S., Yin, 县 Y., Cui, P., Wu, Y., Yang, J., Jiang, C., \& Yang, Q. (2018). Monitoring and biochemical Characterization of Beta-Cypermethrin Resistance in Spodoptera exigua (Lepidoptera: Noctuidae) in Sichuan Province, China. Pesticide Biochemistry and Physiology, 146, 71-79. 